\title{
En ung mann med luftveisinfeksjon og intense smerter
}

\author{
En ung mann med opprinnelse fra Vest-Afrika ble innlagt på sykehus \\ grunnet hoste og sterke smerter i overkroppen. På kort tid ble sykdoms- \\ bildet dramatisk forverret. Pasienten hadde en kjent kronisk sykdom, og \\ historien illustrerer viktigheten av at symptomer på infeksjon tas alvorlig \\ hos slike pasienter.
}

En aktiv idrettsungdom i slutten av tenårene hadde hatt hoste og sekret fra luftveiene i et par dager før han utviklet kraftige smerter $i$ skuldre, bryst og rygg. Han var født og oppvokst i Norge med vestafrikanske foreldre. Som barn hadde han fått påvist sigdcelleanemi. Etter fire dager med luftveisinfeksjon ble smertene så kraftige at han ble innlagt på medisinsk avdeling. Ved undersøkelse var det krepitasjoner på begge lungeflater ved auskultasjon, leukocytose og infiltrater på røntgen thorax. C-reaktivt protein (CRP) var $15 \mathrm{mg} / \mathrm{l}(0,0-10 \mathrm{mg} / \mathrm{l})$.

Hoste, slapphet, krepitasjoner og infiltrater ble tolket som tegn på pneumoni. CRP var kun lett forhøyet, men man antok at det skyldtes at det var tidlig i forløpet. Mottakende lege leste $\mathrm{i}$ journalen at pasienten hadde kjent sigdcelleanemi og skulle ha rikelig intravenøs morfin og væske ved smerter (ramme 1). Av samme grunn valgte man å starte antibiotikabehandling med bred dekning med cefuroksim og erytromycin.

Smertene ble etter hvert så kraftige at pasienten trengte opptil $20 \mathrm{mg}$ morfin intravenøst i timen. Han fikk i tillegg væskeinfusjon med Ringer-acetat. Etter undersøkelse mottak ble han plassert på medisinsk sengeavdeling. I løpet av de neste 6-8 timene ble han sløvere og tiltakende hypoksisk. Til tross for ekstra oksygentilskudd var pulsoksymetrisk oksygenmetning $\left(\mathrm{SpO}_{2}\right)$ nede i $80 \%$. Omtrent 12 timer etter innleggelse ble det erkjent at en fulminant sigdcellekrise var under utvikling, og pasienten ble overført til medisinsk intensivavdeling. På dette tidspunktet var han sløv, men vekkbar, hadde oliguri og svært anstrengt respirasjon.

Pasientens tilstand forverret seg kraftig de neste timene. Ikke-invasiv ventilasjonsstøtte med kontinuerlig overtrykk (CPAP) og BiPAP med økt oksygenmengde $i$ inspirasjonsluften hadde liten effekt, og oksygeneringen av blodet forverret seg stadig. Han ble sirkulatorisk ustabil. Man økte derfor den intravenøse væsketilførselen og ga infusjoner med vasoaktive medikamenter (dopamin og noradrenalin). Ett døgn etter innleggelsen var pasien- ten helt utslitt av det tunge respirasjonsarbeidet og måtte intuberes. Under intubasjonen kom det opp store mengder blodig, skummende væske fra luftveiene. Høyt luftveistrykk var nødvendig for å sikre adekvat ventilasjon. Til tross for $100 \%$ oksygen $i$ inspirasjonsluften lå oksygenmetningen $i$ arterieblod $\left(\mathrm{SaO}_{2}\right)$ rundt $90 \%$ de påfølgende timene.

Transtorakal ekkokardiografi viste sviktende hjertefunksjon på både høyre og venstre side, betydelig dilatasjon av atrium og ventrikkel på høyre side samt økt trykk i pulmonalarterien. På grunn av vedvarende hypotensjon med middelarterietrykk rundt $40-50 \mathrm{~mm} \mathrm{Hg}$ ble det innlagt et lungearteriekateter. Målinger viste at motstanden i systemkretsløpet var redusert til ca. $25 \%$ av normalverdien, mens motstanden $i$ lungekarsengen var økt med mer enn $100 \%$. Fordi det var vedvarende lavt blodtrykk og høyt noradrenalinnivå, ble vasopressin også lagt til. truende kardiopulmonal svikt og akutt dilatasjon av høyre hjertehalvdel på grunn av den høye lungekarmotstanden. Tilførsel av mer væske for å redusere blodets viskositet hadde ikke hatt noen effekt, og lungesvikten var allerede så massiv at man ikke klarte å oppnå normal oksygenering av blodet. En mulig strategi for å stoppe den massive mikrosirkulatoriske emboliseringen som finner sted ved en sigdcellekrise, er å fjerne sigdcellene fra sirkulasjonen. Dette kan gjøres gjennom en utskiftningstransfusjon der man tapper 300-400 ml blod fra en arteriekran eller en stor vene, og deretter gir én pose erytrocyttkonsentrat på vanlig måte. Det må også gis væske for å unngå høyt hemoglobinnivå. Hemoglobinverdier over $10 \mathrm{~g} / \mathrm{dl}$ er ikke gunstig fordi økt viskositet fremmer vasookklusjon (1-4). Samtidig må hemoglobinnivået ikke bli så lavt at man risikerer generell oksygenmangel i mikrosirkulasjonen og ytterligere økt danning av sigdceller. Målet bør derfor være at hemoblobinverdien ligger i området 9-10 g/dl $(3,4)$.

En utskiftningstransfusjon var indisert, men oppstarten ble forsinket fordi det var proble-
Pasienten var nå i en sigdcellekrise med livs-

\author{
Are Bergsvein Tvinnereim \\ uxtvar@ous-hf.no \\ Avdeling for anestesiolog \\ Generell intensiv \\ Helge Opdahl
}

Nasjonalt kompetansesenter for NBC-medisin

\section{Morten Rostrup}

Akuttmedisinsk avdeling

Kjetil Sunde

Avdeling for anestesiologi

Generell intensiv

Oslo universitetssykehus, Ullevål 
RAMME 1

\section{Sigdcelleanemi}

Sigdcellesykdom (sigdcelleanemi) er en arvelig sykdom der erytrocyttene endrer form i oksygenfattig miljø slik at de hindrer blodstrømmen i mikrosirkulasjonen. Sykdommen er sjelden i Norge, men vanlig i visse områder, først og fremst Vest-Afrika. Sykdomsforløpet svinger. Lange symptomfrie perioder kan avløses av alvorlige anfall (sigdcellekriser). Symptomene preges da av intense muskel- og beinsmerter, eventuelt også akutt lungesvikt som i startfasen kan likne på pneumoni.

Profylaktisk behandling $(3,4)$

Behandling med hydroksyurea kan øke mengden føtalt hemoglobin ( $\mathrm{HbF}$ ) i blodet, noe som beskytter mot utvikling av sigdcellekriser. Ikke like effektivt hos alle pasienter.

Behandling ved sigdcellekriser $(3,4)$

- Ekstra oksygen for å sikre arteriell oksygenmetning

- Effektiv smertelindring med intravenøse opiater

- Intravenøs væske

- Eventuell transfusjon av 1-2SAG-enheter (unngå hematokritøkning)

- Eventuell utskiftningstransfusjon

- Antibiotika ved minste mistanke om infeksjon

På grunn av fare for organsvikt ved akutte kriser bør pasienten overvåkes på overvåknings- eller intensivavdeling inntil symptomene er i remisjon.

mer med å få forlikt blod. Man startet derfor med å tappe blod og erstatte volum med klare væsker, etter hvert også med SAG når forliket blod ble tilgjengelig. I løpet av de tolv første timene på intensivavdelingen var totalt $5000 \mathrm{ml}$, altså så å si hele blodvolumet, erstattet.

Kreatinin steg raskt og han utviklet nyresvikt. Kalium, som ved innkomsten var 4,1 $\mathrm{mmol} / \mathrm{l}$ (3,6-5,0 $\mathrm{mmol} / \mathrm{ll}$ ), steg raskt (fig 1). Da kaliumverdier over 7,0 innebærer betydelig fare for arytmier, ble det forberedt oppstart av kontinuerlig venovenøs hemofiltrasjon, og i påvente av dette fikk han infusjon med glukoseinsulin samt kalsiumklorid og Bricanyl intravenøst. Innen dialyse hadde kommet i gang, fikk han imidlertid hjertestans. Det var pulsløs elektrisk aktivitet og asystole (fig 1). Han ble resuscitert i 18 minutter før egen hjertefunksjon var reetablert. Kort etter etablering av egensirkulasjon viste en arteriell blodprøve $\mathrm{pH}$
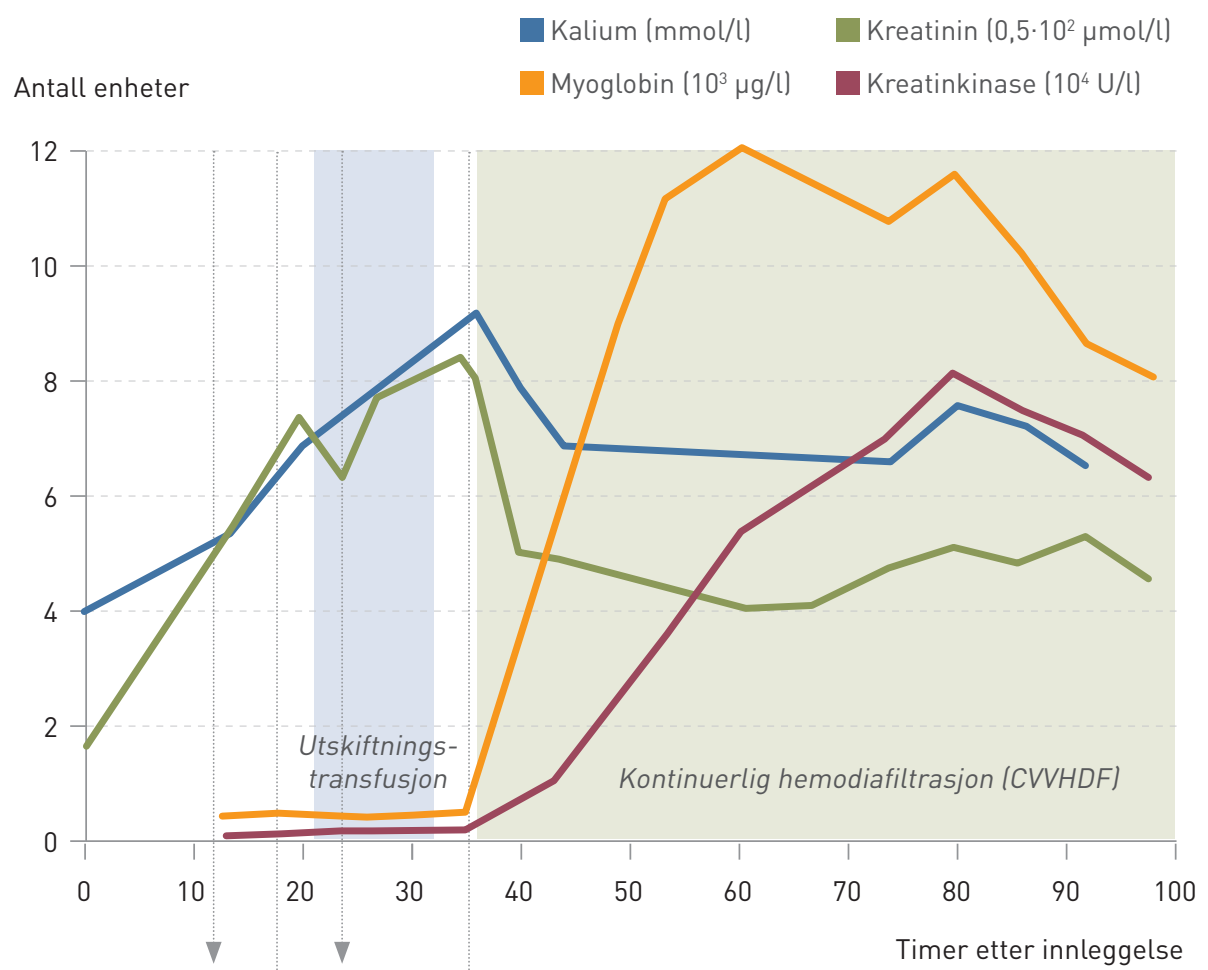

Intensiv- Intubasjon

avdeling

$$
\text { Anuri Hjertestans }
$$

Figur 1 Pasientens sykdomsforløp. Endringer av kaliumnivå, nyrefunksjon (kreatinin) og muskeliskemi (myoglobin, CK)

$6,99(7,35-7,45)$ og laktat $12,7 \mathrm{mmol} / \mathrm{l}$ $10,5-1,6 \mathrm{mmol} / \mathrm{l})$. Sentralvenøs oksygenmetning $\left(\mathrm{SvO}_{2}\right)$ var $21 \%$ (normalt over $75 \%$ ) og var et ytterligere tegn på svært dårlig oksygenering av blodet i mikrosirkulasjonen.

Få timer etter hjertestansepisoden begynte kreatinkinase- (CK) og myoglobinverdiene, som tidligere bare hadde vært moderat forhøyet, å stige kraftig (fig 1). Myoglobin var maksimalt 119894 ug/l (30-70 ug/l) 25 timer etter hjertestansen, mens maksimal CK var 81128 U/l(50-400U/l) 45 timer etter. Muskulaturen, spesielt på underekstremitetene, hadde en svært hard konsistens. Ortoped ble konsultert og konkluderte med at dette skyldtes muskeliskemi pga. okkluderte kar, og dermed ikke et klassisk kompartmentsyndrom som kunne avlastes kirurgisk.

Det forelå altså en uttalt rhabdomyolyse. Ut ifra mønsteret for myoglobin- og CK-frigjøring kan man anta at uttalt vevshypoksi i forbindelse med hjertestans ga en akselererende sigdcelledanning med mikrosirkulatorisk embolisering.

Etter utskiftningstransfusjon, intensivbehandling og dialyse stabiliserte situasjonen seg gradvis i løpet av de neste dagene. Pasienten var imidlertid avhengig av dialyse i ytterligere fire uker og respiratorbehandling i vel seks uker før organfunksjonene var tilfredsstillende. Da pasienten ble utskrevet fra intensivavdelingen, var han mentalt adekvat uten nevrologiske utfall, men hadde betydelig svekkelse av muskulaturen i underekstremitetene etter uttalt myonekrose. Etter ni uker på sykehus ble han utskrevet til et rehabiliteringssenter, der han etter hvert trente seg opp til å gå med krykke. Han kunne ikke fortsette idrettskarrieren, men har startet på høyskoleutdanning.

\section{Diskusjon}

Kasuistikken handler om en ung mann med kjent sigdcelleanemi som legges inn på sykehus med symptomer på luftveisinfeksjon og sterke smerter. I løpet av noen få timer blir tilstanden hans svært kritisk, da han utvikler sigdcellekrise med sviktende lungefunksjon (acute chest syndrome) (5). Historien er en viktig påminner om at infeksjoner og andre sykdommer som påvirker oksygeninnholdet $\mathrm{i}$ blodet hos pasienter med sigdcelleanemi, må tas på største alvor. Selv om intervensjoner som for eksempel utskiftningstransfusjon ikke er garantert å stoppe en sigdcellekrise, er det rimelig å anta at forløpet kunne blitt mindre dramatisk hvis man hadde startet en mer aggressiv overvåkning og behandling direkte etter innleggelsen.

Sigdcelleanemi er en av verdens mest ut- 

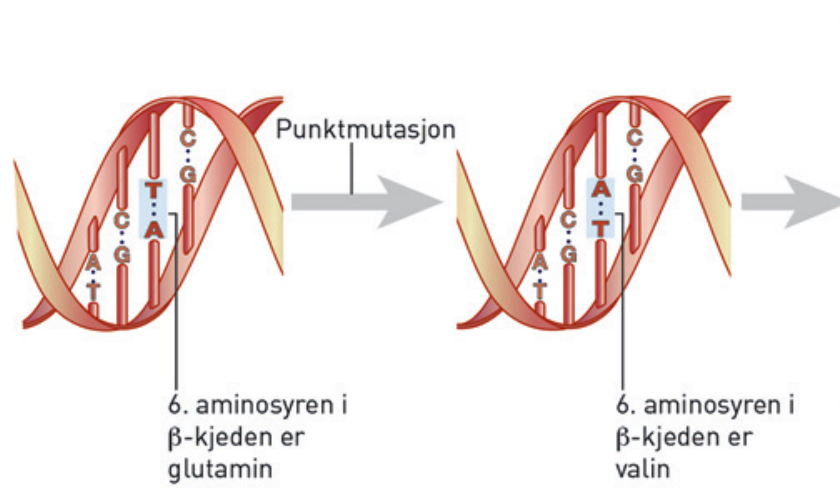

Sigdcellehemoglobin ( $\mathrm{HbS}$ )

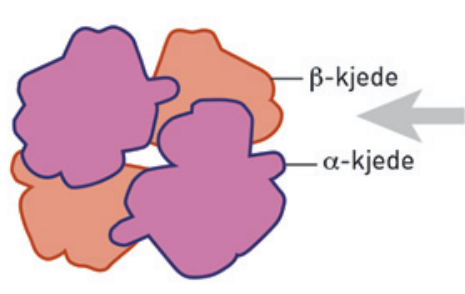

Normalt hemoglobinmolekyl
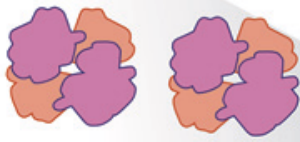

$\infty$

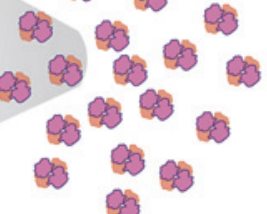

HbA-molekylene reagerer ikke med hverandre; hvert kan transportere oksygen
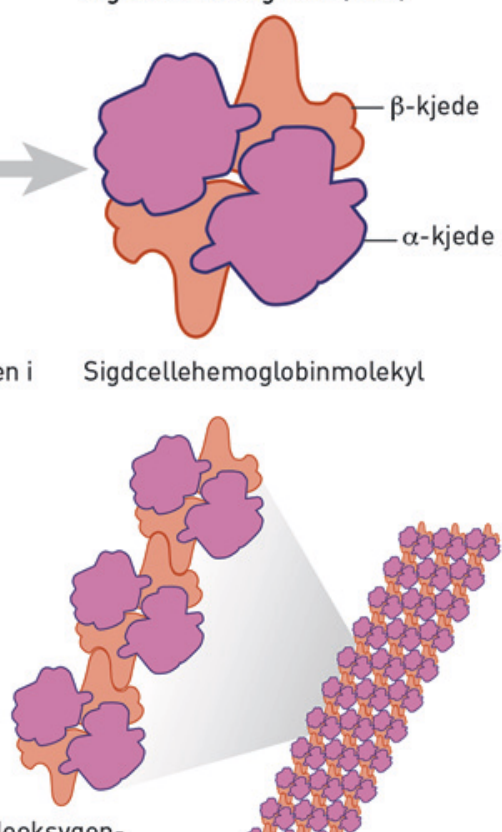

\section{l}

6. aminosyren i Sigdcellehemoglobinmolekyl
$\beta$-kjeden er

$\beta$-kjeder i de deoksygenerte $\mathrm{HbS}$-molekylene reagerer lettere med hverandre og danner polymerer som gir den karakteristiske sigdformen

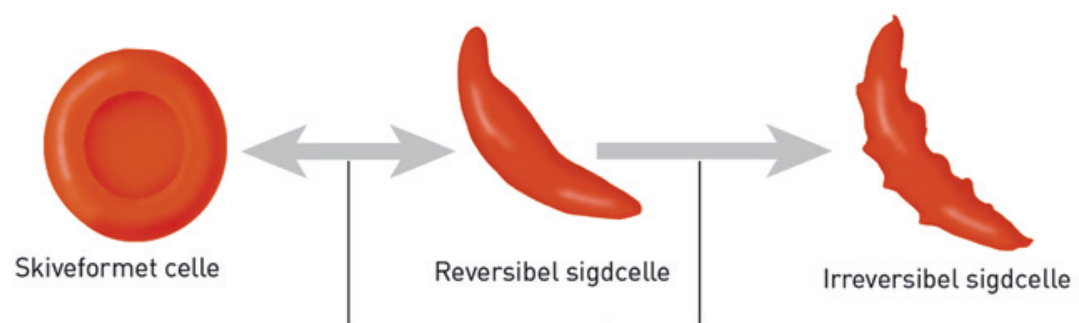

Lavt oksygeninnhold $\mathrm{i}$ mikrosirkulasjonen øker tendensen til overgang fra skive- til sigdform pga. polymerisering. Dersom oksygeninnholdet i blodet normaliseres raskt, kan polymeriseringen reverseres

Når polymerene vedvarer over tid, dannes krystaller som gjør formovergangen irreversibel
HbS-polymer

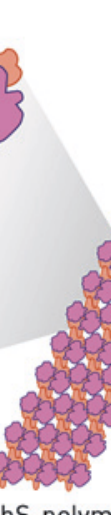


personene er likevel beskyttet mot malaria. For at sykdommen skal gi alvorlige konsekvenser må mengden HbS i blodet være høy, noe som bare forekommer hos homozygote $(\mathrm{HbSS})(1)$. Dette var tilfellet hos vår pasient.

De fleste homozygote vil gjennomgå en eller flere sigdcellekriser i løpet av livet, og sigdcellekrise med lungeaffeksjon er langt den hyppigste dødsårsaken hos denne pasientgruppen (5). Halvparten av dem som blir innlagt på intensivavdeling pga. sigdcellekrise dør, og av disse dør $50 \%$ i løpet av 24 timer $(6,7)$. Vår pasient hadde kjent sigdcellesykdom siden barndommen, og hadde som liten hatt én alvorlig sigdcellekrise. Selv om de fleste homozygote pasienter får sigdcellekriser av varierende alvorlighetsgrad, ses livstruende sigdcellekriser relativt sjelden i Norge. Dette skyldes at andelen innbyggere med genetisk mutasjon er lav. Med økende innvandring må vi forvente at antallet personer med homozygot sigdcellesykdom vil øke også i Norge. Dette gjør at alle sykehusleger og allmennpraktikere kan komme i kontakt med slike pasienter.

Ved høyt HbS-innhold i blodet er luftveisinfeksjoner, dehydrering og hard fysisk aktivitet kjente risikofaktorer som kan utløse en sigdcellekrise. Både muskelsmerter og lungesvikt hos personer med sigdcellesykdom har sammenheng med at blodstrømmen gjennom mikrosirkulasjonen hindres av halvmåne- eller sigdformede erytrocytter, sigdceller (fig 2). Danningen av slike celler skyldes at genetisk endrede hemoglobinmolekyler $(\mathrm{HbS})$ danner polymerer når hemoglobinets oksygenmetning $\left(\mathrm{HbSO}_{2}\right)$ reduseres (1). Polymerisering gjør den intracellulære hemoglobinsuspensjonen mindre deformerbar. Hvis oksygeninnholdet i blodet normaliseres raskt, vil polymeriseringen reverseres. Hvis dette ikke skjer, går $\mathrm{HbS}$ polymerene over til en krystallstruktur, og prosessen blir irreversibel. HbS- krystallene fungerer da som et indre skjelett. Erytrocyttene får den karakteristiske sigdformen og hindres $i$ å tilpasse seg karenes dimensjon under passasjen gjennom mikrosirkulasjonen. Aggregater av erytrocytter og andre blodceller danner mikroembolier og tromboser. Tendensen til polymerisering øker ved enhver tilstand som reduserer oksygeninnholdet i mikrosirkulasjonen. Acidose og høy temperatur øker også polymeriseringen. Ved formforandringen oppstår det også lesjoner i cellemembranen. Kaliumtap fra erytrocyttene kommer derfor som tillegg til kaliumtap fra celler i hypoksiskadet vev $(1,2)$.

Milten er spesielt utsatt for sirkulasjonsforstyrrelser, ettersom den har lavere blodstrømshastighet. På grunn av multiple infarkter over tid vil miltvevet hos mange pasienter erstattes av arrvev. Miltens normale funksjon faller bort, noe som kalles «autosplenektomi». Nedsatt miltfunksjon medfører redusert immunforsvar og økt infeksjonstendens, som er spesielt uheldig for pasienter med sigdcelleanemi. Vaksinasjon mot pneumokokker og Haemophilus influenza samt lav terskel for antibiotikabehandling ved infeksjonsmistanke er derfor viktig hos disse pasientene. I tillegg har rikelig væsketilførsel ved fysisk aktivitet eller sterk varme en beskyttende effekt (4).

Diagnosen sigdcelleanemi stilles ved hemoglobinsubtyping ved kromatografi. Dette utføres ved universitetssykehusene i Norge. Hvis disse pasientene innlegges i sykehus med mistanke om begynnende sigdcellekrise, bør det tas full hematologisk status med blodutstryk og retikulocytter samt utvidet blodgruppeundersøkelse med tanke på transfusjonsbehov.

Pasienten vår sto på hydroksyurea, den eneste profylaksemedisinen som finnes for sigdcelleanemi. Hydroksyurea stimulerer produksjon av føtalt hemoglobin, $\mathrm{HbF}$, slik at den prosentvise mengden $\mathrm{HbS}$ i blodet reduseres. Behandlingen er ikke like effektiv hos alle, og mange pasienter trenger mer enn vanlig startdose $(20 \mathrm{mg} / \mathrm{kg})$ for å få god nok effekt. Voksnes evne til å produsere $\mathrm{HbF}$ varierer betydelig (3), noe som kan forklare variasjonen i behandlingseffekt

En sigdcellekrise kan raskt utvikle seg til å bli livstruende. Riktig intervensjon på et tidlig stadium kan bryte en ond sirkel og redusere skadevirkningene. Kjennskap til sykdomsbildet og behandlingsmuligheter er derfor viktig. Tidlig behandling består av rikelig væsketilførsel, optimal smertelindring, inkludert intravenøs behandling med opioider ved sterke smerter, og ekstra oksygen $\mathrm{i}$ inspirasjonsluften $(3,4)$. Antibiotikabehandling bør også startes tidlig ved mistanke om luftveisinfeksjon. Behandling med rikelig intravenøs væske og oksygen bør startes prehospitalt hvis det er lang vei til sykehus. Terskelen for utskiftningstransfusjon bør være lav hvis tilstanden ikke stabiliserer seg eller går tilbake i løpet av få timer. Ved mistanke om utvikling av sigdcellekrise skal pasienten innlegges på overvåknings- eller intensivavdeling for nøye observasjon og optimal behandling.

Pasienten har gitt samtykke til at artikkelen blir publisert.

\section{Are Bergsvein Tvinnereim (f. 1972)}

er spesialist i anestesiologi og overlege. Forfatter har fylt ut ICMJE-skjemaet og oppgir ingen interessekonflikter.

\section{Helge Opdahl (f. 1942)}

er dr.med., spesialist i anestesiologi og seksjonsoverlege.

Forfatter har fylt ut ICMJE-skjemaet og oppgir ingen interessekonflikter.

\section{Morten Rostrup (f. 1958)}

er dr.med., spesialist i indremedisin og overlege. Forfatter har fylt ut ICMJE-skjemaet og oppgir ingen interessekonflikter.

\section{Kjetil Sunde (f. 1964)}

er dr.med., spesialist i anestesiologi, overlege og professor.

Forfatter har fylt ut ICMJE-skjemaet og oppgir følgende interessekonflikter: Han har mottatt reise- og forelesningshonorar fra Bard Medical som produserer utstyr for terapeutisk hypotermi.

Litteratur

1. Bunn HF. Pathogenesis and treatment of sickle cell disease. N Engl J Med 1997: 337: 762-9.

2. Stuart MJ, Nagel RL. Sickle-cell disease. Lancet 2004; 364: 1343-60

3. Yawn BP. Buchanan GR, Afenyi-Annan AN et al. Management of sickle cell disease: summary of the 2014 evidence-based report by expert panel members. JAMA 2014; 312: 1033-48.

4. Hellebostad M. Handlingsplan for pasienter med sigdcelleanemi. Oslo: Helsebiblioteket, 2007.

5. Vichinsky EP, Styles LA, Colangelo LH et al. Acute chest syndrome in sickle cell disease: clinical presentation and course. Blood 1997; 89: 1787-92.

6. Cecchini J, Lionnet F, Djibré M et al. Outcomes of adult patients with sickle cell disease admitted to the ICU: a case series. Crit Care Med 2014; 42 : 1629-39

7. Gardner K, Bell C, Bartram JL. Outcomes of adults with sickle cell disease admitted to critical careexperience of a single institution in the $\mathrm{UK} . \mathrm{Br}$ J Haematol 2010; 150: 610-3.

Mottatt 26.9. 2014, første revisjon innsendt 12.1 2015, godkjent 13.2. 2015. Redaktør: Lise Mørkved Helsingen. 